\title{
STUDI PENGGUNAAN ANTIBIOTIK NON RESEP DI APOTEK KOMUNITAS KOTA KENDARI
}

\section{STUDY OF NON PRESCRIPTION USE OF ANTIBIOTICS ON COMMUNITY PHARMACY IN KENDARI}

\author{
Sunandar Ihsan, Kartina, Nur Illiyin Akib \\ Fakultas Farmasi Universitas Halu Oleo, Kendari, Sulawesi Tenggara \\ Email: iksan.elrumi@yahoo.com
}

\begin{abstract}
ABSTRAK
Penggunaan antibiotik memerlukan pertimbangan klinis yang tepat untuk memenuhi rasionalitas, sehingga menjamin keamanan, ketepatan dan efektivitas yang maksimal. Penggunaan yang tidak tepat akan menimbulkan masalah resistensi yang berdampak pada morbiditas dan mortalitas penyakit infeksi maupun kerugian ekonomi dan sosial yang tinggi. Penelitian ini bertujuan untuk mengetahui tingkat penggunaan antibiotik tanpa resep di apotek komunitas Kota Kendari yang ditinjau dari perilaku pasien dan pengetahuan pasien serta faktor-faktor yang mempengaruhi penggunaan antibiotik tanpa resep dokter yaitu konsumen apotek. Penelitian ini bersifat deskriptif, dilakukan di 10 apotek yang ditetapkan dengan cluster random sampling dan 287 konsumen apotek yang dipilih dengan accidental sampling. Instrumen penelitian yang digunakan adalah kuesioner pengetahuan pasien. Hasil penelitian menunjukkan pasien cenderung pernah menggunakan antibiotik tanpa resep dokter dengan tingkat pengetahuan pasien kurang $(56,44 \%)$. Penggunaan antibiotik terkait perilaku adalah sebagian besar pasien memperoleh antibiotik di apotek (94,07\%), sumber informasi dalam menggunakan antibiotik adalah dokter $(43,90 \%)$, jenis penyakit yang diobati adalah gejala demam $(54,34 \%)$, jenis antibiotik yang sering digunakan adalah amoksisilin (54,34\%), pembelian antibiotik untuk satu kali pengobatan adalah $87,80 \%$. Faktor-faktor yang mempengaruhi penggunaan antibiotik tanpa resep adalah: sebagian besar diperoleh dari riwayat kebiasaan sebelumnya yang tidak pernah menggunakan resep dokter $87,45 \%$, jika ditinjau berdasarkan pengalaman sebelumnya dari resep dokter subyek menggunakan antibiotik tanpa resep karena gejala dan obat yang sama 89,89\%, sebagian besar karena pengalaman penggunaan sebelumnya yang memberi hasil baik $75,26 \%$ dan subyek tetap menggunakan antibiotik $(77,70 \%)$ meski tidak memiliki pengetahuan tentang penyakitnya. Tingginya penggunaan antibiotik tanpa resep di Kota Kendari ditinjau dari perilaku pasien dan pengetahuan serta faktor yang mempengaruhinya dapat menimbulkan kerugian baik secara klinis maupun secara ekonomi.
\end{abstract}

Kata kunci: antibiotik tanpa resep, perilaku pasien, tingkat pengetahuan 


\begin{abstract}
The use of antibiotics needs appropriate clinical judgement to assure safety, properly and effectivity. Antimicrobial ressistance associated with inappropriate antibiotics use leading mortality and morbidity infectious disease gives negative impact of economy and social in society. The aim of this study is to determine the prevalence of purchase of antibiotics without prescription in community pharmacys in Kendari based on behaviour and knowledge of patient and predisposition factors of non prescription use of antibiotics. It is a description study towards to 10 community pharmacy with cluster random sampling and 287 pharmacy costumer with accidental sampling. Instrument analysis used patient knowledge questionnaire. The result of this study show that tended to use of non prescription antibiotics with patient's knowledge were less (56.44\%). The use of non prescription antibiotics related with patient behaviour is the largest percentage was $94.07 \%$ and obtained in community pharmacies, with phsycian is a source of information (43.90\%). Type of symptoms of disease is fever were $54.70 \%$, with amoxicillin is a frequently used (54.34\%). Purchased of antibiotics for once treatment is $87.80 \%$. Factors that affecting of non prescription use of antibiotics were the previous habits of antibiotics used without prescription (87.45\%), and based on prescription drugs of antibiotics it is because the same of drug and symptoms that's used before were $89.89 \%$, with mainly therapeutics result are good for previous treatment (75.26\%). Subject used of antibiotics with lack of knowledge for his illness were $77.70 \%$.
\end{abstract}

Keywords: non prescription antibiotics, patient behaviour, level of patient knowledge

\title{
PENDAHULUAN
}

Antibiotik adalah obat yang berasal dari seluruh atau bagian tertentu mikroorganisme dan digunakan untuk mengobati infeksi bakteri. Antibiotik ada yang bersifat membunuh bakteri dan membatasi pertumbuhan bakteri. Penggunaan antibiotik telah lama digunakan untuk melawan penyakit akibat infeksi oleh mikroorganisme terutama bakteri. Antibiotik yang pertama kali dihasilkan adalah penisilin golongan $\beta$ laktam yang berspektrum sempit hanya untuk bakteri gram negatif dan kemudian spektrumnya meluas. Setelah itu antibiotik banyak dihasilkan seperti golongan sefalosforin, makrolida, kuinolon, aminoglikosida (Tripathi, 2008).

Penggunaan antibiotik yang tidak rasional akan menyebabkan masalah resistensi, dimana bakteri mengembangkan kemampuan secara genetik menjadi 
kurang atau tidak peka terhadap antibiotik melalui mekanisme resistensi yang didapat, resistensi yang dipindahkan dan mutasi spontan. Resistensi juga dapat bersifat nongenetik ketika bakteri dalam keadaan istirahat namun akan kembali sensitif jika bakteri tersebut aktif kembali. Resistensi silang terjadi pada antibiotik yang memiliki struktur kimia yang hampir sama atau berbeda tetapi cara kerja yang hampir sama seperti eritromisin dan linkomisin (Tripathi, 2008).

Masalah resistensi akibat penggunaan obat yang tidak rasional salah satunya disebabkan oleh penggunaan yang tidak sesuai dengan kondisi klinik pasien yang dapat terjadi akibat penggunaan antibiotik tanpa resep dokter. Hal ini dipicu terutama mudahnya masyarakat memperoleh antibiotik tanpa mempertimbangkan atau mendapatkan nasehat dan rekomendasi dari tenaga kesehatan yang berwenang terutama oleh dokter dan juga apoteker. Pembelian antibiotik di sarana kesehatan terutama apotek dilakukan oleh masyarakat dalam rangka swamedikasi atau pengobatan sendiri tanpa mendapat penjelasan yang memadai tentang aturan penggunaan maupun indikasi yang sesuai.

Pengobatan dengan antibiotik tanpa resep dokter tidak hanya terjadi di negaranegara berkembang melainkan juga di negara-negara maju. Swamedikasi menggunakan antibiotik yang tinggi ditemukan di negara-negara Eropa seperti Romania dan Lithuania (Al-Azzam et al., 2007). Adapun penelitian yang dilakukan di Brazil menunjukkan bahwa 74\% dari 107 apotek yang telah dikunjungi, termasuk 88\% apotek yang didaftar oleh Municipal Health Secretary menjual antibiotik tanpa resep dokter (Volpato et al., 2005). Spanyol telah menetapkan peraturan bahwa antibiotik tidak dapat dijual tanpa resep dokter. Tetapi dari 108 apotek yang menjual antibiotik, hanya 57 apotek (52,8\%) menjelaskan bahwa mereka tidak dapat memberikan antibiotik secara bebas untuk menghindari resistensi antibiotik (Llor and Cost, 2009).

Swamedikasi telah diatur oleh peraturan pemerintah yang merupakan upaya masyarakat dalam mengobati dirinya sendiri dalam bentuk obat wajib apotek (OWA) yaitu obat yang diserahkan tanpa resep dokter. Untuk swamedikasi, antibiotik kurang 
mendapatkan aturan yang cukup jelas berdasarkan SK Menkes No. 347 tahun 1990, karena tidak semua antibiotik masuk sebagai OWA. Antibiotik yang masuk OWA hanya dalam bentuk sediaan salep dan cair. Berdasarkan Undang-Undang Obat Keras St. No. 419 tgl. 22 Desember 1949, antibiotik termasuk obat keras (daftar G). Untuk distribusi obat daftar $\mathrm{G}$ diatur dalam pasal 3 ayat 1 bahwa obat-obat daftar $\mathrm{G}$ penyerahan dan atau penjualan untuk keperluan pribadi adalah dilarang. Oleh karena itu penggunaan antibiotik tanpa resep dokter pada dasarnya adalah melanggar peraturan pemerintah baik Undang-Undang obat keras maupun SK Menkes tahun 1990.

Perkembangan pelayanan kefarmasian kini menuntut perubahan paradigma bahwa pekerjaan kefarmasian tidak hanya berfokus pada obat namun juga berorientasi pada kepentingan pasien. Oleh karena itu pemerintah membuat aturan untuk menjamin keselamatan pasien dengan mempertimbangkan konteks pelayanan kefarmasian yang baru dalam bentuk Peraturan Menteri Kesehatan (PMK) nomor 35 tahun 2014 tentang standar pelayanan kefarmasian di apotek sebagai hasil revisi dari PMK sebelumnya nomor 1027 tahun 2004. Dalam PMK yang baru ini disebutkan bahwa salah satu tugas apoteker adalah pelayanan farmasi klinik yang didalamnya memuat pelayanan informasi obat dan konseling pasien. Namun peraturan yang baru ini tidak menjadikan penggunaan antibiotik menjadi legal meski apoteker dapat saja melakukan pelayanan informasi obat antibiotik maupun konseling mengenai penggunaan antibiotik. Hal ini dikarenakan sesuai peraturan tentang antibiotik, untuk mendapat antibiotik harus melalui resep dokter. Oleh karenanya konseling pada pasien berupa penggunaan antibiotik tanpa resep dokter dilakukan pada dasarnya hanya sebatas memberi saran untuk mengarahkan pasien agar ke dokter dan sejauh memberi penjelasan kebaikan dan keburukan penggunaaan antibiotik yang tidak tepat, sebab jika farmasis memilihkan antibiotik maka hal tersebut akan melanggar Undang-Undang tentang peredaran antibiotik. Penelitian ini bertujuan untuk mengetahui tingkat penggunaan antibiotik tanpa resep dokter dari perspektif 
pengetahuan dan perilaku masyarakat di apotek-apotek Kota Kendari serta mengetahui faktor-faktor yang mempengaruhi penggunaan antibiotik tanpa resep dokter.

\section{METODE PENELITIAN}

Penelitian ini merupakan penelitian deskriptif. Data diambil menggunakan kuisioner untuk menilai tingkat pengetahuan dan perilaku masyarakat yang membeli antibiotik di apotek. Sampel apotek diambil sebanyak 10 buah yang dipilih berdasarkan perwakilan daerah yang dibagi berdasarkan 10 kecamatan di Kota Kendari. Sampel pasien yaitu konsumen apotek diambil secara aksidental berdasarkan rata-rata pasien yang berkunjung selama 1 bulan atau $10 \%$ dari jumlah pasien selama 1 bulan yang didapat sebanyak 287 responden. Kriteria sampel responden penelitian ini antara lain pasien yang membeli antibiotik tanpa resep dokter, berusia di atas 18 tahun, tingkat pendidikan minimal SMA, bersedia menjawab lembar kuesioner yang diberikan.

Instrumen yang digunakan dalam penelitian ini adalah kuesioner dan panduan wawancara. Secara umum kuisioner ditujukan kepada pelanggan apotek terdiri dari 9 pertanyaan untuk melihat bagaimana tingkat pengetahuan pasien terkait penggunaan antibiotik tanpa resep dokter, 6 pertanyaan untuk melihat perilaku pasien terhadap penggunaan antibiotik tanpa resep dokter, dan 5 pertanyaan untuk melihat faktorfaktor yang mempengaruhi penggunaan antibiotik tanpa resep dokter. Tingkat pengetahuan pasien terhadap penggunaan antibiotik dibagi dalam 3 kategori yaitu (Wuwur, 2012):

a) Baik : $>80 \%$ (jika yang menjawab benar $\geq 8$ dari 9 pertanyaan)

b) Cukup : $\geq 60 \%$ - $<80 \%$ (jika yang menjawab benar $\geq 6$ dari 9 pertanyaan)

c) Kurang: $<60 \%$ (jika yang menjawab benar $\leq 5$ dari 9 pertanyaan) 


\section{HASIL DAN PEMBAHASAN}

A. Karakteristik Responden

Karakteristik 287 responden dideskripsikan berdasarkan jenis kelamin, tingkat pendidikan dan usia seperti pada Tabel I. Jumlah responden wanita mendominasi $51,91 \%$ meski tidak berbeda jauh dengan responden pria 48,09\%. Hal ini mengindikasikan bahwa kecenderungan mengobati diri sendiri lebih banyak dilakukan oleh perempuan baik untuk keluarga maupun untuk diri sendiri. Kepedulian perempuan terhadap penyakit adalah sebagai bentuk tanggung jawab dan rasa kasih yang dimiliki oleh kaum perempuan baik sebagai ibu maupun untuk keperluan perawatan diri sendiri untuk keperluan penguatan dalam keluarga (Harun, 2015).

Penggunaan antibiotik tanpa resep lebih banyak pada tingkat pendidikan SMA $63,07 \%$ dibanding perguruan tinggi 36,97\%. Hal ini menunjukkan bahwa tingkat pendidikan mempengaruhi pengambilan keputusan untuk menggunakan obat secara rasional. Semakin tinggi tingkat pengetahuan seseorang maka semakin baik dalam menentukan keputusan menggunakan obat yang baik dan benar.

Tabel I. Karakteristik Responden

\begin{tabular}{lcc}
\hline Karakteristik & Jumlah $(\boldsymbol{\Sigma})$ & Persen $(\boldsymbol{\%})$ \\
\hline Jenis kelamin & & \\
$\quad$ Pria & 138 & 48,09 \\
$\quad$ Wanita & 149 & 51,91 \\
Tingkat pendidikan & & \\
$\quad$ SMA & 181 & 63,07 \\
$\quad$ Akademi/perguruanTinggi & 106 & 36,93 \\
Usia & & \\
$\quad \leq 30$ tahun & 151 & 52,61 \\
$\quad \geq 30$ tahun & 136 & 47,39 \\
\hline Total & 287 & 100 \\
\hline
\end{tabular}

Jika dilihat dari umur responden maka umur di bawah 30 tahun lebih banyak dibanding di atas 30 tahun. Tidak terlalu jelas apakah umur di bawah 30 tahun adalah juga tingkat pendidikan lebih rendah dibanding di atas 30 tahun, namun kemungkinan 
korelasi umur dan tingkat pendidikan saling berhubungan dengan tingkat pendidikan SMA yang tidak melanjutkan ke perguruan tinggi di Kota Kendari cukup banyak. Hal ini perlu penelitian lebih lanjut, termasuk pola penyakit yang berkaitan dengan penyakit infeksi termasuk infeksi menular seksual. Penelitian oleh Hajar (2015) menunjukkan bahwa penyakit menular seksual di Kota Kendari lebih banyak terjadi pada anak usia remaja putus sekolah.

B. Gambaran Penggunaan Antibiotik Tanpa Resep Dokter

Tingkat penggunaan antibiotik tanpa resep dokter diketahui dengan menggunakan kuisioner yang meliputi tiga parameter, yaitu untuk melihat bagaimana tingkat pengetahuan pasien terhadap penggunaan antibiotik yang terdiri dari 9 pertanyaan, untuk melihat perilaku pasien terhadap penggunaan antibiotik tanpa resep dokter yang terdiri dari 6 pertanyaan, dan untuk melihat faktor-faktor yang mempengaruhi penggunaan antibiotik tanpa resep dokter terdiri dari 5 pertanyaan.

1. Tingkat Pengetahuan Responden

Tingkat pengetahuan dinilai dengan menggunakan 3 kategori yaitu baik bila menjawab 8-9 pertanyaan dengan benar, kategori cukup bila responden menjawab 6-7 pertanyaan dengan benar, dan kategori kurang bila responden menjawab $\leq 5$ pertanyaan dengan benar. Tingkat pengetahuan responden dapat dilihat pada Tabel II.

Tabel II. Profil tingkat pengetahuan pasien

\begin{tabular}{lcc}
\hline \multicolumn{1}{c}{ Kategori } & $\boldsymbol{\Sigma}$ Pasien & \% Pasien \\
\hline Baik & 45 & 15,68 \\
Cukup & 80 & 27,88 \\
Kurang & 162 & 56,44 \\
\hline Total & 287 & 100 \\
\hline
\end{tabular}

Sumber: data primer yang diolah

Berdasarkan hasil observasi didapatkan bahwa, tingkat pengetahuan responden terhadap antibiotik umumnya termasuk kategori kurang sebesar 56,44\%, dengan kategori baik hanya 15,68\%. Hal ini dapat dilihat dari distribusi jawaban benar pasien 
terkait pengetahuan tentang antibiotik bahwa sebagian besar responden menganggap penggunaan antibiotik cukup satu tablet yaitu 61,68\%. Responden juga tidak dapat membedakan jenis-jenis dari antibiotik 60,98\%. Demam adalah indikasi penggunaan antibiotik menurut sebagian besar responden 54,70\%. Masih banyak responden yang menganggap bahwa penggunaan antibiotik memiliki cara dan efek yang sama 48,09\% dan tidak harus diminum sampai habis 47,73\%. Responden (37,63\%) juga menganggap bahwa antibiotik dalam bentuk sirup untuk anak masih dapat digunakan walaupun setelah lebih dari 2 minggu serta masih ada responden yaitu 32,06\% yang menganggap bahwa antibiotik digunakan untuk sakit kepala.

2. Perilaku Responden Terkait Penggunaan Antibiotik Tanpa Resep Dokter

Berdasarkan pengamatan pada perilaku konsumen terkait penggunaan antibiotik tanpa resep dokter didapatkan bahwa sebagian besar $(94,07 \%)$ konsumen yaitu responden mendapat antibiotik di apotek. Yang menarik adalah antibiotik juga didapatkan di warung kelontong sekitar 2,43\% dan dari kerabat 3,48\% mengindikasikan peredaran antibiotik kurang terkontrol. Hal ini membutuhkan pengawasan baik tingkat pemerintah terkait yaitu BPOM dan Dinas Kesehatan maupun masyarakat karena obat golongan obat keras hanya dapat diperoleh di apotek bukan di toko obat dan lebih-lebih di toko kelontong.

Sumber informasi yang didapat oleh konsumen (responden) terkait penggunaan antibiotik adalah kebanyakan dari dokter yaitu 43,90\% dan melanjutkan pengobatan dari dokter 16,37\%. Apoteker sebagai sumber informasi justru sangat kecil yaitu $12,54 \%$ sama seperti saran dari kerabat atau teman. Dibanding saran dari apoteker, penggunaan antibiotik tanpa resep lebih banyak didasari oleh kemauan sendiri atas pengalaman sebelumnya yaitu $14,63 \%$. Jika tanpa saran dari tenaga kesehatan maka potensi penggunaan antibiotik yang tidak rasional akan lebih besar menimbulkan masalah berupa resistensi yang berdampak pada peningkatan penyakit infeksi, dan kerugian ekonomi untuk mengatasi penyakit yang semakin meluas akibat resistensi antibiotik. 
Perilaku responden yang juga diamati adalah terkait persediaan antibiotik untuk digunakan sewaktu-waktu yaitu sebesar 53,31\%. Hal ini berpengaruh terhadap kualitas obat jika penyimpanan tidak memenuhi syarat karena akan menganggu stabilitas obat tersebut. Oleh karena itu penggunaan antibiotik dalam hal penyimpanannya perlu mempertimbangkan syarat penyimpanan yang hal ini juga terkait dengan pola konsumsi bahwa antibiotik harus dihabiskan bukan untuk dipakai sewaktu-waktu karena berpengaruh terhadap farmakokinetika dan farmakodinamika obat (Winter, 2013).

Perilaku terkait gejala penyakit yang diobati adalah gejala flu 26,13\%, demam $31,35 \%$ dan radang tenggorokan $12,54 \%$. Jenis antibiotik yang paling banyak digunakan adalah amoksisilin 54,34\%, ampisilin 21,64\%, dan siprofloksasin 8,36\%. Jenis lain yang juga cukup banyak dicari adalah tetrasiklin 4,5\% dan sefadroksil 4,87\%. Pemberian antibiotik jika tidak berdasarkan pemeriksaan klinis dan mikrobiologi maka akan berpotensi pada penggunaan yang tidak tepat (Leekha et al., 2011). Pemberian antibiotik untuk gejala klinis penyakit seharusnya juga diberikan atas indikasi yang jelas dan secara ideal pemberian antibiotik harus didasarkan pada hasil pemeriksaan dan berdasarkan faktor pasien seperti umur, berat badan dan fungsi renal (Ritter et al., 2008). Penggunaan antibiotik juga harus dipastikan kebutuhannya, jangka waktu penggunaan sesuai dengan yang ditetapkan serta tergantung macam infeksi dan keparahannya sehingga tidak terjadi resistensi.

Informasi dari tenaga kesehatan terkait pembelian antibiotik menunjukkan bahwa sebagian besar $87,80 \%$ konsumen membeli semua antibiotik setelah diberi anjuran. Faktanya masih terdapat juga konsumen yang membeli separuhnya dari yang dianjurkan yaitu 12,19\%. Hal tersebut mengindikasikan bahwa anjuran untuk menggunakan antibiotik hanya sebatas informasi untuk menghabiskan obatnya yang tercermin dari jawaban benar terkait pengetahuan untuk penggunaan sampai habis $52,27 \%$. Jika dilihat dari pemberi informasi untuk membeli semua, maka yang memberi anjuran tersebut sebagian besar bukan apoteker karena saran untuk membeli antibiotik dari apoteker hanya $12,54 \%$, dengan sebagian besar antibiotik didapat di 
apotek 94,07\%. Apoteker dalam melaksanakan fungsinya harusnya memberi informasi terkait cara penggunaan, efek samping, dosis, lama penggunaan untuk menjamin penggunaan antibiotik yang rasional (Tjay dan Rahardja, 2007).

C. Faktor-Faktor yang Mempengaruhi Penggunaan Antibiotik Tanpa Resep Dokter

Faktor yang mempengaruhi penggunaan antibiotik dilihat berdasarkan pada: pertama yaitu riwayat kebiasaan penggunaan sebelumnya yang tidak dengan resep dokter, kedua; ditinjau berdasarkan penggunaan sebelumnya dari resep dokter, ketiga; berdasarkan alasan pengalaman hasil penggunaan sebelumnya, dan keempat berdasarkan pada tahu atau tidaknya pasien terhadap penyakitnya. Dari hasil penelitian didapatkan sejumlah $87,45 \%$ adalah dari kebiasaan pasien menggunakan antibiotik tanpa resep dokter sebelumnya dan hanya sejumlah $12,54 \%$ yang tidak pernah menggunakan antibiotik tanpa resep dokter sebelumnya. Alasan responden memiliki kebiasaan menggunakan antibiotik tanpa resep dokter dari penggunaan sebelumnya yaitu sejumlah $37,28 \%$ telah mengetahui jenis antibiotik yang diperlukan dan sejumlah $34,49 \%$ melanjutkan resep pengobatan dari dokter, serta karena lebih murah $28,21 \%$.

Faktor kedua penyebab responden menggunakan antibiotik tanpa resep yang ditinjau dari pengalaman penggunaan dengan resep dokter sebelumnya adalah responden merasa memiliki gejala penyakit yang sama dan mengulang pengobatan sebelumnya yaitu $89,89 \%$. Resep antibiotik tidak dapat diulang tanpa persetujuan dokter yaitu dengan menuliskan "iter" akan tetapi hal ini jarang terjadi. Kenyataannya, masih banyak pasien yang mengulang resep dokter dan tidak mengkonfirmasikan kepada dokter yang bersangkutan. Faktor ketiga penyebab penggunaan antibiotik tanpa resep adalah pengalaman penggunaan sebelumnya yang memberikan hasil yang baik yaitu terjadi pada $75,26 \%$ responden. Walaupun hasil penggunaan antibiotik baik, hal ini tidak tepat karena penggunaan antibiotik hanya dapat diperoleh dengan menggunakan resep dokter dan tidak semua jenis penyakit memberikan tanda dan gejala yang sama, sehingga pengobatan tidak dapat disamakan 
(Tjay dan Rahardja, 2007). Faktor keempat penyebab penggunaan antibiotik tanpa resep dokter adalah dinilai berdasarkan atas tahu tidaknya responden akan penyakit yang dideritanya yaitu sebanyak $77,70 \%$ responden tetap menggunakan antibiotik meski tidak tahu apa sebenarnya penyakit yang dideritanya.

Berdasarkan hasil penelitian ini dapat dilihat bahwa peredaran antibiotik sangat bebas terjadi di masyarakat tanpa melalui resep dokter. Peredaran antibiotik ini pertama melanggar peraturan perundang-undangan, kedua kurangnya pengawasan dari pihak yang berwenang dalam hal ini Dinas Kesehatan terkait maupun BPOM. Kemenkes telah mengeluarkan Peraturan Menteri Kesehatan Republik Indonesia Nomor 2406/Menkes/Per/XII/2011 tentang Pedoman Umum Penggunaan Antibiotik bahwa penggunaan antibiotik hanya dengan resep dokter. Namun orientasi apotek yang mengarah pada money oriented menyebabkan obat yang seharusnya dilarang penjualannya tanpa resep dokter masih dapat dengan bebas diperoleh di apotek tanpa resep. Lemahnya fungsi kontrol dan instrumen hukum menyebabkan penjualan obat keras secara bebas terus berlangsung di apotek. Dalam Peraturan Menteri Kesehatan nomor 75 tahun 2016 disebutkan bahwa pengawasan dan pembinaan terhadap obat dan perbekalan kesehatan dilakukan oleh BPOM. Oleh karena itu peran BPOM sangat penting dan diperlukan untuk melakukan pengawasan terhadap peredaran antibiotik di sarana kesehatan terutama apotek karena penggunaan antibiotik yang berlebihan dapat menimbulkan kerugian baik secara ekonomi maupun secara klinis berupa resistennya antibiotik tersebut terhadap berbagai mikroba.

\section{KESIMPULAN}

Tingkat pengetahuan responden terkait penggunaan antibiotik tanpa resep, sebagian besar termasuk kategori rendah $(56,44 \%)$. Perilaku responden terkait penggunaan antibiotik diperoleh tanpa resep dokter sebagian besar di apotek 94,07\% dengan sumber informasi dari dokter hanya $43,90 \%$, penyakit yang diobati terbanyak untuk demam 54,34\% dengan jenis terbanyak adalah amoksisilin dengan penggunaan sekali. 
Faktor yang mempengaruhi penggunaan antibiotik tanpa resep dokter adalah: sebagian besar diperoleh dari riwayat kebiasaan sebelumnya yang tidak pernah menggunakan resep dokter 87,45\%, jika ditinjau berdasarkan pengalaman sebelumnya dari resep dokter responden menggunakan antibiotik tanpa resep karena gejala dan obat yang sama $89,89 \%$, sebagian besar karena pengalaman penggunaan sebelumnya yang memberi hasil baik dan responden tetap menggunakan antibiotik meski tidak memiliki pengetahuan tentang penyakitnya.

\section{DAFTAR PUSTAKA}

Al-Azzam, S.I., Al-Husein, B.A., Alzoubi, F., Masadeh, M.M., and Al Horani, M.A.S., 2007, Self-Medication with Antibiotics in Jourdanian Populations, International Journal of Occupational and Medicine and Enviromental Health, 20 (4): 373-380.

Hajar, S., 2015, Rasionalitas Penggunaan Antibiotik pada Penyakit Menular Seksual di Kota Kendari, Skripsi, Fakultas Farmasi, Universitas Halu Oleo, Kendari.

Harun, M.Q.A.R., 2015, Rethinking Peran Perempuan dalam Keluarga, Karsa, Jurnal Sosial dan Budaya Keislaman, 23 (1).

Leekha, S., Terrel C.L., and Edson, R.S., 2011, General principles of antimicrobial therapy, Introduction to the Symposium on antimicrobial therapy, Mayoclinic Proceeeding, 86 (2): 86-87.

Llor, C. and Cost, J.M., 2009, The Sale of Antibiotics without Prescription in pharmacies in Catalonia, Spain, Clinical Infectious Disease Oxfrod Journal, 48 (10): 1345-1349.

Ritter, J.M., Lewis, L.D., Mant, T.G.K., and Ferro, A., 2008, A Textbook of Clinical Pharmacology and Therapeutics, $5^{\text {th }}$ Edition, by Hodder Arnold an imprint of Hodden Education, UK, 323-324.

Tripathi, K.D., 2008, Antimicrobial drugs: general consideration. Essential of medical pharmacology, $6^{\text {th }}$ Edition. Jaypee brothers medical publishers, 666, 668-670. 
Tjay, T.H. dan Rahardja, K., 2007, Obat-Obat Penting, Jakarta: Penerbit PT. Elex Media Komputindo.

Volpato, D.E., Souza, B.V., Rosa, L.G.D., Melo, L.H., Daudt, C.A.S, and Deboni, L., 2005, Use of Antibiotics withhout Medical Prescription, BJID, 9 (4).

Winter, 2010, Basic Clinical Pharmacokinetics, $5^{\text {th }}$ Edition, Lippincot Williams and Wilkins, USA., alih bahasa oleh Setiawati M.C.N., Mutiarawati, Keban S.A., Penerbit Buku Kedokteran ECG, Jakarta, 1-3, 25-26, 30-34.

Wuwur, L.N., 2012. Studi Penggunaan Antibiotik Tanpa Resep Dokter di Beberapa Apotek di Kecamatan Rungkut Surabaya Timur, Skripsi, Surabaya, Fakultas Farmasi Universitas Surabaya. 